\title{
Antiviral Activity of an Extract from Leaves of the Tropical Plant Cynometra cauliflora
}

\author{
Noor Zarina Abd Wahab ${ }^{1, *}$, Aziah Azizul' ${ }^{1}$ Norhidayah Badya², Nazlina Ibrahim ${ }^{3}$
}

\author{
Noor Zarina Abd Wahab ${ }^{1, *}$, Aziah \\ Azizul' ${ }^{1}$ Norhidayah Badya², \\ Nazlina Ibrahim ${ }^{3}$ \\ 'Department of Biomedicine, Faculty of \\ Health Sciences, Universiti Sultan Zainal \\ Abidin, Terengganu, MALAYSIA. \\ ${ }^{2}$ Faculty of Medicine, Universiti Sultan Zainal \\ Abidin, Terengganu, MALAYSIA. \\ ${ }^{3}$ Department of Biological Sciences and \\ Biotechnology, Faculty of Science and \\ Technology, Universiti Kebangsaan, Bangi, \\ MALAYSIA.
}

\section{Correspondence}

\section{Noor Zarina Abd Wahab}

Department of Biomedicine, Faculty of Health Sciences, Universiti Sultan Zainal Abidin, Terengganu, MALAYSIA.

E-mail: zarinawahab@unisza.edu.my

History

- Submission Date: 05-02-2021;

- Review completed: 03-03-2021.

- Accepted Date: 16-03-2021.

DOI : $10.5530 /$ pj.2021.13.96

Article Available online http://www.phcogj.com/v13/i3

Copyright

(C) 2021 Phcogj.Com. This is an open access article distributed under the terms of the Creative Commons Attribution 4.0 International license.

\section{ABSTRACT}

Background: Cynometra cauliflora is a species of tree in the family Fabaceae and has been used in folk medicinal preparation. Objectives: In this study, Cynometra cauliflora methanolic leaves extract was tested against clinical isolate herpes simplex virus type-1 (HSV-1). Materials and Methods: The leaves of $C$. cauliflora plant was extracted using methanol extraction method. Cytotoxicity was assessed using 3-(4,5-dimethylthiazol-2,5-diphenyltetrazolium bromide (MTT) assay. Plaque reduction assays were carried out to evaluate the antiviral activity of $C$. cauliflora extract against HSV-1. These include post-treatment, pre-treatment and virucidal assays. Results: The value of cytotoxic concentration, $\mathrm{CC}_{50}$ of $C$. cauliflora extract was $36 \mathrm{mg} /$ $\mathrm{mL}$. High antiviral activity was observed in post-treatment. $C$. cauliflora extract treatment was found to not interfere directly to infectious particle and confer mild protection when given as prophylaxis. Conclusion: This study provides important novel insights on the phytomedicinal properties of $C$. cauliflora extracts on HSV-1.

Key words: Herpes simplex virus type 1, Cynometra cauliflora, plaque reduction assay, (3-(4,5-dimethylthiazol-2-yl)-2,5-diphenyltetrazolium bromide); virucidal.

\section{INTRODUCTION}

Medicinal plants of the Malaysian forest were reportedly rich in biological activities. Several interesting natural products were isolated from local medicinal plants such as styrylpyrone derivatives isolated from G. umbrosus have shown a potent antiviral activity against HSV-1 and dengue virus type 2 (DENV-2). ${ }^{1-3}$ Other in vitro studies also showed SPD is active against several cancer cell lines namely; HL-60 (leukemia), HepG2 (liver), PANC-1 and Hela cells, ${ }^{4-5}$ geraniin extracted from the rind of Nephelium lappaceum that were reported has been shown to exhibit antiviral properties against several types of viruses, as well as crude methanolic extract of Psidium guajava leaves extract that were reported to have antibacterial activities against foodborne pathogens. ${ }^{6}$ This plant extract also was reported to have antiviral activity against DENV-2. ${ }^{7}$ Previous studies have shown antioxidant, antiinflammatory, antitumor, antimicrobial and antidiabetic activity of C. cauliflora. ${ }^{8-10}$ C. cauliflora L. or commonly known as 'Nam-Nam' among native Malaysian is a tropical plant under the Fabaceae family. It is also commonly known by local as NamNam or Buah Katak Puru in Malaysia. ${ }^{11}$ The fruit which are kidney-shape pod, greenish yellow to brown, with a sandy and wrinkled surface. It can be consumed as fruit salad (ulam). ${ }^{12}$

Herpes Simplex Virus type-1 (HSV-1) is a common pathogen which causes cold sores or common cold and orolabial infection. Normal sites of infection are mucosal epithelium, hence keratitis labial herpes, gingivostomatitis, and genital herpes. Infection can disseminate from mucosal epithelium to other tissues with slow healing and more detrimental outcome in immunocompromised individual. ${ }^{13}$ This includes in newborn babies, transplant patient or HIV patient who are readily struggling with immature immunity, immune suppressive drugs regiment and prolonged toxicity and prophylaxis, respectively. ${ }^{14}$ Generally, HSV-1 infections can be treated successfully with acyclovir. However, drug resistant variants emerged as a result of long-term treatment of immunocompromised patients with acyclovir. This subsequently led to treatment failure. ${ }^{15}$ Thus, a new target is required to ensure alternative possible treatments for HSV-1 resistant strains. In order to combat this resistant HSV-1 strain, new antiviral agents with different mode of actions are indeed important. Therefore, the aim of this study was to investigate the potential of crude methanolic extract of C. cauliflora leaves as an antiviral agent against HSV-1 infection.

\section{MATERIALS AND METHODS}

\section{Plant material}

The fresh leaves parts were collected from the state of Terengganu, Malaysia. The leaves were cleaned with tap water to remove dirt and oven-dried at $60^{\circ} \mathrm{C}$. Dried leaves powder of C. cauliflora was extracted with methanol. C. cauliflora leaves $(100 \mathrm{~g})$ was macerated with methanol $(300 \mathrm{~mL})$ to produce crude methanol extract. The extracts were filtered and solvent was evaporated under reduced pressure using rotary vacuum evaporator.

\section{Cells and virus}

Vero cell from American Type Culture Collection (ATCC) CCL-81 was used for both cytotoxicity and antiviral test. Dulbecco's Modified Eagle's Medium

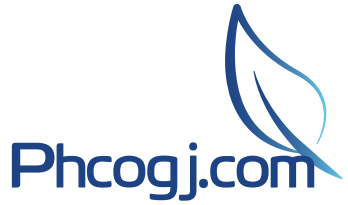

Cite this article: Wahab NZA, Azizul A, Badya N, Ibrahim N. Antiviral Activity of an Extract from Leaves of the Tropical Plant Cynometra cauliflora. Pharmacog J. 2021;13(3): 752-7. 
(DMEM) (SigmaAldrich, USA) supplemented with $5 \%$ fetal bovine serum (FBS) (Sigma- Aldrich, USA) was used for cell maintenance throughout the experiment. Clinical strain of HSV-1 used was obtained from the stock culture of Faculty Science and Technology, Universiti Kebangsaan Malaysia.

\section{Cytotoxicity test}

Briefly, Vero cells $\left(2.5 \times 10^{5}\right.$ cells $\left./ \mathrm{mL}\right)$ were seeded into 96 -well plates and incubated overnight at $37^{\circ} \mathrm{C}$. Upon $80 \%$ confluence, the cells were treated with several concentrations of extract, ranging from $3.13 \mathrm{mg} / \mathrm{mL}$ to $100 \mathrm{mg} / \mathrm{mL}$. After incubation of about $72 \mathrm{~h}$, the growth medium was discarded and replaced with $100 \mu \mathrm{L}$ of MTT solution and incubated for 3h. After that, the MTT solution was discarded, and formazan crystal was dissolved using $100 \mu \mathrm{L}$ of dimethyl sulphoxide (DMSO) to lyse the cells. Colour development was detected using a microplate reader (TECAN Infinite $200 \mathrm{PRO}$, Austria) at $540 \mathrm{~nm}$. Optical density (OD) of individual well was quantified using spectrophotometer at $540 \mathrm{~nm} .{ }^{16}$ Cells viability was calculated using formula below:

Cell viability (\%) = ODtest - ODblank / ODcell - ODblank x 100

where ODtest $=$ optical absorbance of cells treated with SPD, ODblank = optical absorbance for well filled with DMSO and OD-cells = optical absorbance for cells without treatment with SPD. Nonlinear regression was done to obtain the CC50 value (cytotoxic concentration which killed $50 \%$ of cells).

\section{Antiviral assay}

Antiviral activity was also evaluated by the plaque assay method. Screening for antiviral activity was performed using 3 different treatments. ${ }^{17}$ 1) Post-treatment: To evaluate antiviral activity of extract against intracellular replication of DENV-2, cells were inoculated with virus 2 hour before treatment with extract. 2) Pre-treatment: In order to determine the prophylactic anti-HSV-1 activity of extract, virus was inoculated to cells 24 hours after treatment with extract. 3) Virucidal: Direct virucidal effect of the extract was investigated by incubating virus with extract for 1 hour before it was inoculated on the cells. For the antiviral tests, the extract concentration tested was twice lower than the $\mathrm{CC}_{50}$ value in order to reduce the possibility of toxicity towards the cells. The viral concentration used for cell inoculations was fixed at $50 \mathrm{PFU}$. The effectiveness of extract as an antiviral agent expressed as selectivity index (SI).

Selectivity Index $(\mathrm{SI})=$ Cytotoxicity concentration $\left(\mathrm{CC}_{50}\right) /$ Effective concentration $\left(\mathrm{EC}_{50}\right)$

\section{RESULTS}

\section{Cytotoxicity evaluation of $C$. cauliflora extract}

MTT assay was conducted to determine the cytotoxicity of C. cauliflora extract towards Vero cells. The cytotoxicity assay result, as presented in Figure 1, shows the percentage of cell viability versus $C$. cauliflora extract concentration. The estimated $\mathrm{CC}_{50}$ value towards the Vero cells was $36.0 \mathrm{mg} / \mathrm{mL}$.

\section{Anti-HSV-1 activity of C. cauliflora}

Plaque reduction assays were done to screen for anti-HSV-1 activity using $C$. cauliflora extract with different concentrations. Figure 2A, 2B and $2 \mathrm{C}$ shows the percentage of plaque reduction in post-treatment, pre-treatment and virucidal assays, respectively. The results from posttreatment assay showed that $100 \%$ plaque reduction was achieved at the concentration of $18 \mathrm{mg} / \mathrm{mL}$. In pre-treatment assay, more than $50 \%$ plaque reduction was observed at $9 \mathrm{mg} / \mathrm{mL}$. Meanwhile, C. cauliflora extract at any concentrations had no virucidal effect on HSV-1.

Effectiveness of certain compounds or extracts can be evaluated by using selective index (SI). In post-treatment assay, C. cauliflora extract exhibited potent antiviral activity against HSV-1 with $\mathrm{EC}_{50}=2.14 \mathrm{mg} /$ $\mathrm{mL}$ and with SI value of 16.8 (Table 1). Pre-treatment of Vero cells with $C$. cauliflora extract exhibited the prophylactic activity of extract against HSV-1 infection with $\mathrm{EC}_{50}=8.5 \mathrm{mg} / \mathrm{mL}$ and with SI value of 4.23 (Table 1). C. cauliflora extract when added simultaneously with the virus not showed any anti-adsorption activity against HSV-1 (Table 1). Result revealed that $C$. cauliflora extract had greater SI value in posttreatment. Any antimicrobial compound that has SI values higher than 10 (SI>10) ensures the potential to be developed as an agent of antiviral drug. ${ }^{18}$ Selectivity index of C. cauliflora extract against HSV-1 was more than 10 indicating potential as antiviral agent.

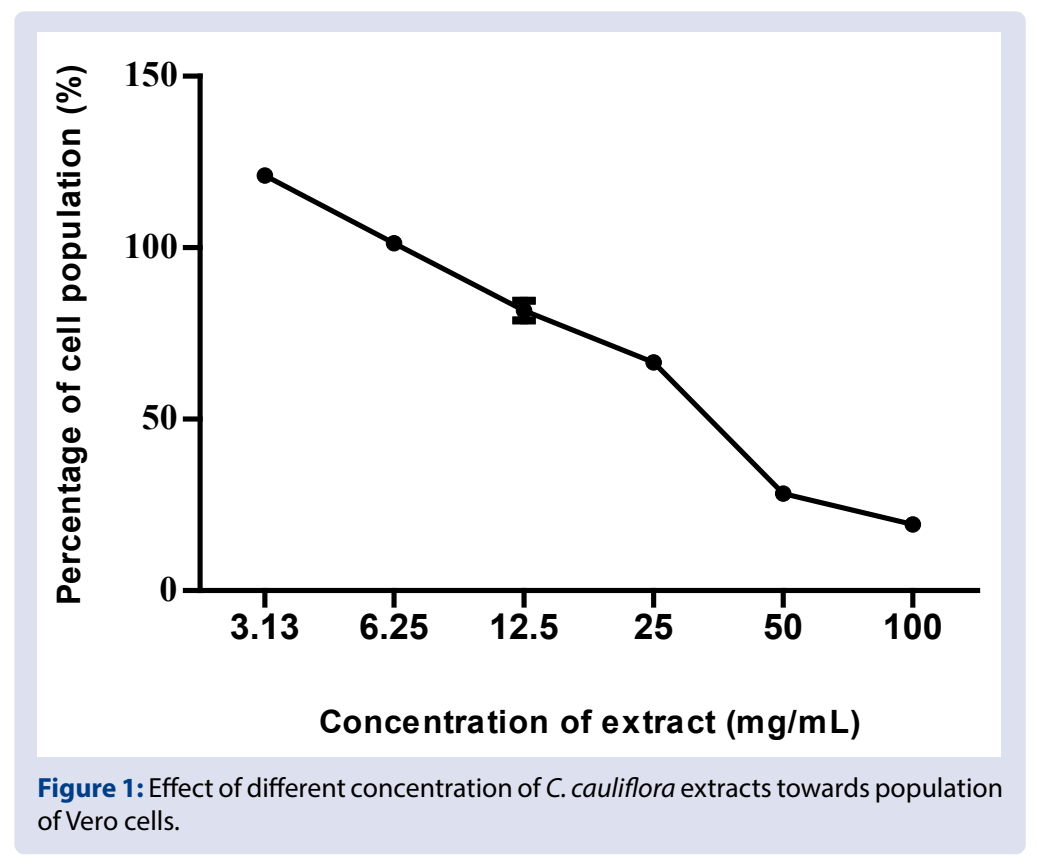




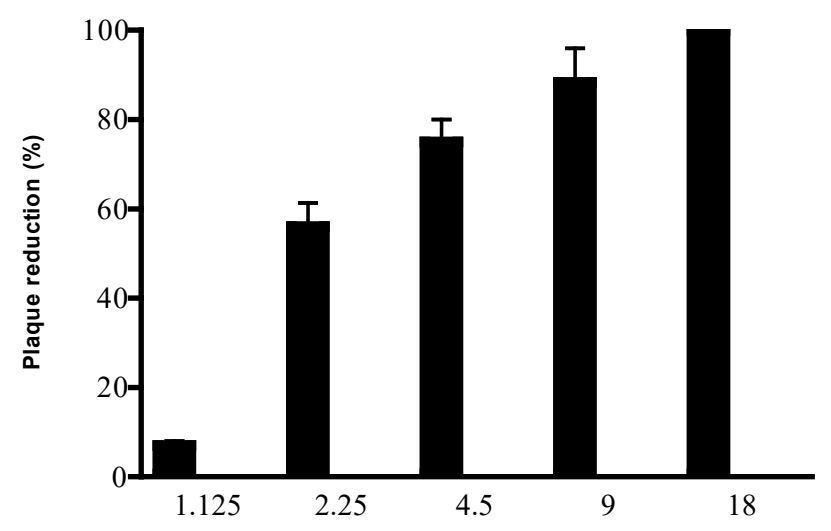

(A)

Extract concentration $(\mathrm{mg} / \mathrm{mL})$

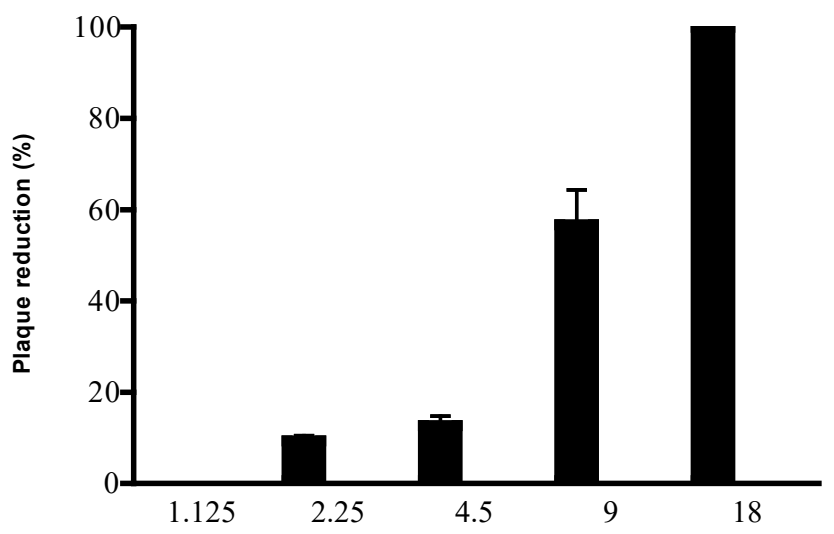

(B)

Extract concentration $(\mathrm{mg} / \mathrm{mL})$

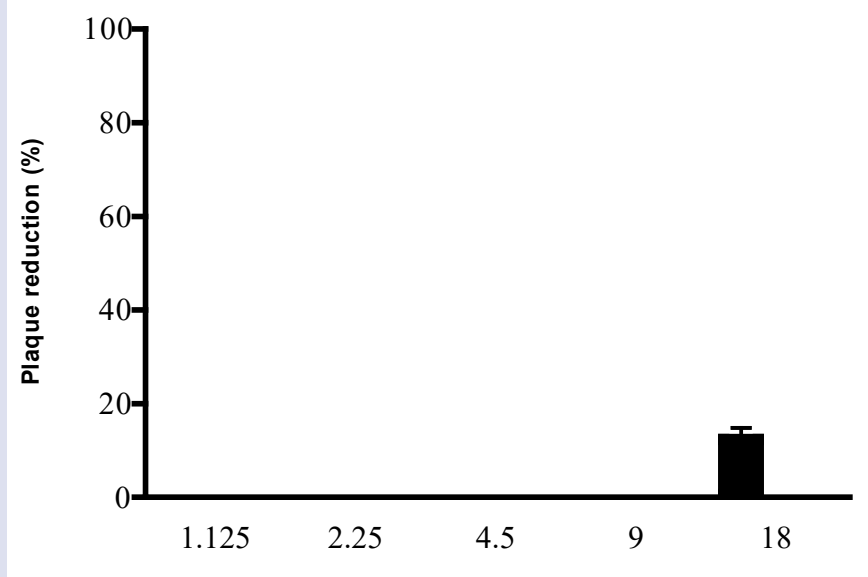

(C)

Extract concentration $(\mathrm{mg} / \mathrm{mL})$

Figure 2: Effect of post-treatment (A), pre-treatment (B) and virucidal (C) of C. cauliflora extract on HSV-1 plaque reduction.

Table 1: $\mathrm{CC}_{50^{\prime}} \mathrm{EC}_{50}$ and SI values of all extracts in post-treatment assay, pre-treatment assay and virucidal assay.

\begin{tabular}{cccc}
\hline & $\mathrm{CC}_{50}(\mathrm{mg} / \mathrm{mL})$ & $\mathrm{EC}_{50}(\mathrm{mg} / \mathrm{mL})$ & $\mathrm{SI}_{\left(\mathrm{CC}_{50} / \mathrm{EC}_{50}\right)}$ \\
\hline Post-treatment & 36.0 & 2.14 & 16.8 \\
Pre-treatment & 36.0 & 8.5 & 4.23 \\
Virucidal & 36.0 & - & -
\end{tabular}

$\mathrm{CC}_{50}$ : Cytotoxic concentration of SPD; $\mathrm{EC}_{50}$ : Effective concentration of SPD; SI: Degree of selectivity. 


\section{DISCUSSION}

Based on phytochemical analyses the findings in previous study, $C$ cauliflora leave extract has been reported to be rich in secondary metabolites such as tannin, flavonoid, saponins, cardiac glycosides and terpenoids. ${ }^{19}$ Lyu and collaborator ${ }^{20}$ reported the elucidation of the mechanism of the antiherpetic (HSV-1) activity in vitro via plaque reduction assay of flavonoid. Similarly, Sieniawska ${ }^{21}$ demonstrated that tannins and related compounds, exhibit antiherpes activity in vitro. In addition, Perez $^{22}$ reported that saponins inhibit the replication of HSV-1 and poliovirus type 2 as shown by inhibition of cytopathic effect and reduction of virus production. Thus, the richness of secondary metabolites in C. cauliflora plant may contribute to antiHSV-1 properties. In this study, we investigated whether C. cauliflora methanolic extracts could confer protection to cells before or after the initiation of HSV-1 infection. The ability of the extract to act directly against HSV-1 virion particle was observed in virucidal assay. This antiviral analysis was performed on Vero cells as a model of infection in mammalian cells.

Screening for antiviral activity involves post-, pre- and virucidal treatment to determine the best mode for antiviral administration. In this part of the study, C. cauliflora extract treatment was found to not interfere directly to infectious particle and confer mild protection when given as prophylaxis. Instead, evidence showed that extract-HSV-1 treatment most effective when administered as post-treatment. C. cauliflora extract anti-HSV-1 activity was observed to be concentration dependent. The ability of $C$. cauliflora to confer protection to the cells before HSV-1 infection was tested by pretreating the cells with $C$. cauliflora methanol extracts for $24 \mathrm{~h}$ prior to viral infection. Protection could be conferred through extracellular mechanisms. The C. cauliflora extracts might interrupt the interaction of several envelope glycoproteins with cell surface receptors requires for fusion of the virion envelope with a cell plasma membrane, resulting in ineffective viral infection. ${ }^{23}$ Pre-treatment was done to study the effect of the extract as prophylactic agent in protecting the cell from HSV-1 adsorption and penetration. $C$. cauliflora extracts presented low to mild prophylactic effects, perhaps due to the presence of various plant alkaloids in the crude extract of C. cauliflora, which may act synergistically to decrease the effective interaction of the active compounds. Additionally, the results are presented as some of the antiviral compounds in these extracts may be present at low levels in a non-cytotoxic dilution of the extract. ${ }^{24}$ Therefore, extract can act as partial prophylactic agent to protect Vero cells against HSV-1 infection. Virucidal agents are chemical substances that attack and inactivate the extracellular viral particles by damaging the protein coat or penetrating the virion or by destroying the viral genome resulting in decreased infectivity of the virus. ${ }^{25}$ The possibility of this occurring was demonstrated using a virucidal assay. C. cauliflora extract treatment was found to not interfere directly to infectious particle because no inhibition was observed.

\section{CONCLUSION}

As a conclusion, our findings suggest that crude extract prepared from C. cauliflora contains antiviral active compounds and could be potential antiviral agent.

\section{ACKNOWLEDGEMENTS}

We wish to thank Universiti Sultan Zainal Abidin (UniSZA) for the facilities and laboratory instruments.

\section{CONFLICTS OF INTEREST}

None.

\section{REFERENCES}

1. Md Nor NS, Ibrahim N. Styrylpyrone derivative of goniothalamus umbrosus inhibit HSV-1 infection during viral early replication cycle. Antiviral Research. 2011;90:A21-78.

2. Ibrahim N, Shahar S, Wahab NZA, Nor NSM. Effect of styrylpyrone derivative (SPD) and SPD/foscarnet combination towards virus infected cell. The 2018 UKM FST Postgraduate Colloquium AIP Conf. Proc. 2019;2111:040002-1-4.

3. Noor Zarina AW, Nazlina I. In vitro study, antiviral activity of styrylpyrone derivative against dengue virus type 2. Asian Journal of Plant Sciences 2020;19:438-42.

4. Inayat-Hussain SH, Annuar BO, Din LB, Ali AM, Ross D. Loss of mitochondrial transmembrane potential and caspase-9 activation during apoptosis induced by the novel styryl-lactone goniothalamin in HL-60 leukemia cells. Toxicology in vitro: An International Journal Published in Association with BIBRA. 2003;17(4):433-9.

5. Hawariah A, Stanslas J. In vitro response of human breast cancer cell lines to the growth-inhibitory effects of styrylpyrone derivative (SPD) and assessment of its antiestrogenicity. Anticancer Res. 1998;18(6A):4383-6.

6. Nurul Alia A, Noor Zarina AW, Noor Ayunie M, Azlin SS, Ahmad Syibli O. Antimicrobial Activity of Psidium guajava Leaves Extract Against Foodborne Pathogens. International Journal of Psychosocial Rehabilitation. 2020;24(7):2020.

7. Noor Zarina AW, Norhidayah B, Nazlina I, Mohd Khairul Amri K, Hafizan J, et al. Antiviral Activity of Cynometra Cauliflora Leaves Methanolic Extract Towards Dengue Virus Type 2. International Journal of Engineering \& Technology. 2018;7 (3.14):344-7.

8. Abd Aziz AF, lqbal M. Antioxidant Activity and Phytochemical Composition of Cynometra cauliflora. J Exp Integr Med. 2013;3(4):337-41.

9. Tajudin TJ, Nashriyah Mat SA, Siti-Aishah AB, Aziz A, Yusran M, Alwi $A$, et al. Cytotoxicity, antiproliferative effects, and apoptosis induction of methanolic extract of Cynometra cauliflora Linn. Whole fruit on human promyelocytic leukemia HL-60 cells. Evidence-Based Complementary and Alternative Medicine. 2012;1-6.

10. Khoo HE, Azlan A, Kong KW, Ismail A. Phytochemicals and Medicinal Properties of Indigenous Tropical Fruits with Potential for Commercial Development. Evidence-Based Complementary and Alternative Medicine. 2016;1-20.

11. Marbawi H, Sidi Ahmad SN, Baharudin NS, Gansau JA. In vitro embryo germination and callus induction of Cynometra cauliflora, an underutilized medicinal plant. Transactions on Science and Technology. 2016;3(3):476-82.

12. Lim TK. Edible Medicinal and Non-Medicinal Plants. 2012

13. Horbul JE, Schmechel SC, Miller BRL, Rice SA, Southern PJ. Herpes simplex virus-induced epithelial damage and susceptibility to human immunodeficiency virus type 1 infection in human cervical organ culture. PLoS ONE 2011;6(7):e22638.

14. Shin H, Iwasaki A. Generating protective immunity against genital herpes. Trends in Immunology 2013;34(10):487-94.

15. Krawczyk A, Arndt MAE, Grosse-Hovest L, Weichert W, Giebel B, Dittmer $U$, et al. Overcoming drug-resistant herpes simplex virus (HSV) infection by a humanized antibody. Proceedings of the National Academy of Sciences. 2013;110(17):6760-5.

16. Mosmann T. Rapid colorimetric assay for cellular growth and survival: Application to proliferation and cytotoxicity assays. Journal of Immunological Methods. 1983;65(1-2):55-63.

17. Moses M, Md. Nor, NS, Ibrahim N. In vitro virucidal activity of a styrylpyrone derivative against herpes simplex virus strain KOS-1. AIP Conference Proceedings. 2014;1614562.

18. Dargan DJ. Methods in Molecular Medicine. 1998;Totowa, New Jersey: Humana Press. 
19. Noor Zarina AW, Norhidayah B, Nazlina I, Mohd Khairul Amri K. Phytochemistry and antibacterial activity of Cynometra Cauliflora. Indian Journal of Public Health Research \& Development. 2019;10(04):765-9.

20. Lyu S-Y, Rhim J-Y, Park W-B. Antiherpetic activities of flavonoids against herpes simplex virus type 1 (HSV-1) and type 2 (HSV-2) in vitro. Arch Pharm Res. 2005;28(11):1293-301.

21. Sieniawska E. Activities ofTannins-from in vitro Studies to ClinicalTrials. Natural Product Communications. 2015;10(11),1934578X1501001.
22. Perez RM. Antiviral Activity of Compounds Isolated from Plants. Pharmaceutical Biology. 2003;41(2):107-57.

23. Antoine TE, Park PJ, Shukla D. Glycoprotein targeted therapeutics: a new era of anti-herpes simplex virus-1 therapeutics. Reviews in Medical Virology. 2013;23(3):194-208.

24. Semple SJ, Reynolds GD, O'Leary MC, Flower RLP. Screening of Australian medicinal plants for antiviral activity. J Ethnopharmacol. 1998;60:163-72.

25. Galabov AS. Virucidal agents in the eve of manorapid synergy. GMS Krankenhhyg Interdiszip, 2007;2(1):18.

\section{GRAPHICAL ABSTRACT}

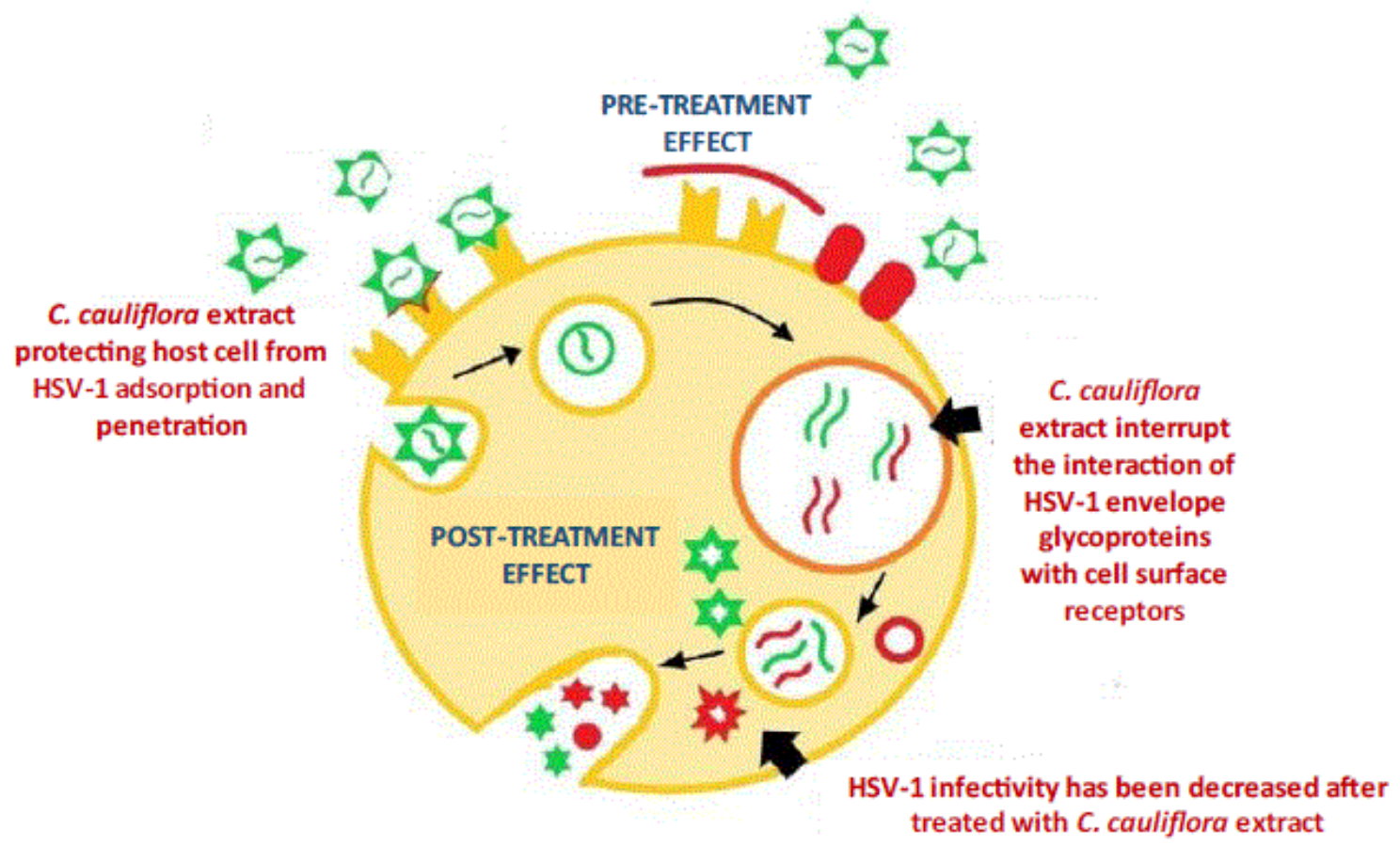

Mechanism of action of $\mathrm{C}$. cauliflora extract antivirus activity against HSV-1

\section{ABOUT AUTHORS}

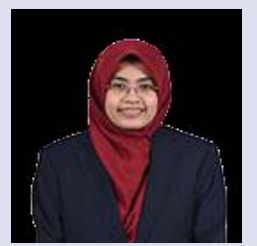

Dr. Noor Zarina Abd Wahab is senior lecturer at the Department of Biomedicine, Faculty of Health Sciences, Universiti Sultan Zainal Abidin, Malaysia. Her current research interest are antimicrobial mechanism of action and biological activity of plant natural products.

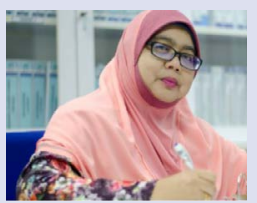

Associate Professor Dr. Nazlina Ibrahim is senior lecturer at the Department of Biological Sciences and Biotechnology, Faculty of Science and Technology, Universiti Kebangsaan, Malaysia. Her current study is evaluation and determination of antimicrobial activities from plant, endophytes and synthetic chemicals. She also is interested in evaluating the toxicity of antimicrobial agents in cell culture and in animals. 


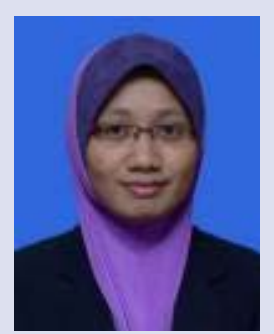

Dr. Norhidayah Binti Badya is senior lecturer at the Faculty of Medicine, Universiti Sultan Zainal Abidin. Her current research interest are biomedical sciences, infectious/ communicable diseases, molecular cell biology and epigenetics.

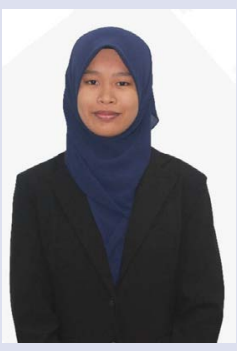

Aziah Azizul is postgraduate student of the Department of Biomedicine, Faculty of Health Sciences, Universiti Sultan Zainal Abidin, Malaysia under supervision of Dr. Noor Zarina Abd Wahab.

Cite this article: Wahab NZA, Azizul A, Badya N, Ibrahim N. Antiviral Activity of an Extract from Leaves of the Tropical Plant Cynometra cauliflora. Pharmacog J. 2021;13(3): 752-7. 